\title{
Use of Ultrasound to Assess the Response to Therapy for Secondary Hyperparathyroidism
}

\author{
Mario Meola, MD, PhD, ${ }^{1,2}$ Ilaria Petrucci, $M D,{ }^{2}$ Elisa Colombini, $M D,{ }^{2}$ and \\ Giuliano Barsotti, $M D^{2}$
}

\begin{abstract}
Secondary hyperparathyroidism (SHPT) is a common complication in patients with chronic kidney disease. In SHPT, the biology of parathyroid cells changes significantly toward diffuse nodular hyperplasia. Currently, diagnosis of SHPT is based on intact parathyroid hormone serum levels and parameters of mineral metabolism. The morphologic diagnosis of SHPT relies on high-resolution ultrasonography with color Doppler imaging. This report describes a maintenance hemodialysis patient with severe SHPT treated using conventional therapy (phosphate binders and oral/intravenous vitamin D or analogues) and the subsequent addition of a calcimimetic. The role of color Doppler ultrasonography in the diagnosis, clinical follow-up, and assessment of therapeutic response of SHPT is discussed. This case suggests that the availability of calcimimetics has changed the natural history of clinical SHPT and may change the therapeutic utility of parathyroidectomy. Use of color Doppler ultrasonography further supports these therapeutic advances, allowing evaluation of the morphologic and vascular changes in hyperplastic parathyroid glands and aiding clinical, pharmacologic, and surgical strategies.

Am J Kidney Dis. 58(3):485-491. (C) 2011 by the National Kidney Foundation, Inc.
\end{abstract}

INDEX WORDS: Parathyroid sonography; neck high-resolution sonography; secondary hyperparathyroidism; calcimimetic cinacalcet; parathyroid hyperplasia.

\section{INTRODUCTION}

Secondary hyperparathyroidism (SHPT) is a serious complication of chronic kidney disease and maintenance hemodialysis (HD) therapy. Hypocalcemia, phosphate retention, and 1,25 dihydroxyvitamin $\mathrm{D}_{3}$ deficiency are the stimuli behind the synthesis and release of parathyroid hormone $(\mathrm{PTH}) .{ }^{1,2}$ Loss of renal mass results in persistent overstimulation of the parathyroid glands, resulting in changes to their cell biology, triggering cell hypertrophy-hyperplasia, and leading to the selection of cell clones with decreased calcium receptor and vitamin D receptor density. ${ }^{1}$

Long-term hyperstimulation of the parathyroid glands produces glandular hyperplasia, which is at first polyclonal, then monoclonal and nodular, progressing to a growth disorder (tertiary hyperparathyroidism). ${ }^{3}$ Nodular hyperplasia does not involve all glands or affect all patients with chronic kidney disease equally; therefore, it can be assumed that unknown genetic mechanisms may be involved.,

The identification of healthy parathyroid glands is difficult. However, high-resolution ultrasonography (US) with color Doppler imaging can be used to localize hyperplastic glands. Color Doppler US is the only technique that measures volumetric variations of the hyperplastic glands and provides semiquantitative parameters on glandular perfusion. ${ }^{6}$

In this report, we describe a maintenance HD patient with severe SHPT treated using conventional therapy (phosphate binders and oral/intravenous vitamin D or analogues), then percutaneous ethanol injec- tion, and finally the calcimimetic cinacalcet. We emphasize the role of color Doppler US to assess the response to therapy for SHPT.

\section{CASE REPORT}

\section{Clinical History and Initial Laboratory Data}

We present the case of a 51-year-old woman undergoing maintenance HD therapy since 1981 because of bladder exstrophy, urinary obstructive, and reflux uropathy with recurrent urinary tract infections. At 12 years of age, after multiple reconstructive surgeries, serum creatinine was $2.5 \mathrm{mg} / \mathrm{dL}$ [221 $\mu \mathrm{mol} / \mathrm{L}]$ ). Cystography showed bilateral vesicoureteral reflux with grade IV hydronephrosis. A ureteral-sigmoidal-cutaneostomy was performed, but glomerular filtration rate progressively worsened. At the age of 22 years (serum creatinine, $12 \mathrm{mg} / \mathrm{dL}[1,060.8 \mu \mathrm{mol} / \mathrm{L}]$, her estimated glomerular filtration rate, calculated using the MDRD (Modification of Diet in Renal Disease) Study equation, was $5 \mathrm{~mL} / \mathrm{min}[0.08$ $\mathrm{mL} / \mathrm{s}]$, so she started maintenance HD treatment. In 1990, after 9 years of maintenance HD therapy and continuous oral therapy with calcium carbonate, $4 \mathrm{~g} / \mathrm{d}$, serum calcium level was $11 \mathrm{mg} / \mathrm{dL}$ (2.64 $\mathrm{mmol} / \mathrm{L})$, serum phosphorus level was $4.9 \mathrm{mg} / \mathrm{dL}(1.58 \mathrm{mmol} / \mathrm{L})$,

From the ${ }^{1}$ S. Anna School of Advanced Studies and ${ }^{2}$ Nephrology and Dialysis Unit, Department of Internal Medicine, University of Pisa, Italy.

Received October 7, 2010. Accepted in revised form March 4, 2011. Originally published online June 30, 2011.

Address correspondence to Mario Meola, MD, PhD, Nephrology and Dialysis Unit, Department of Internal Medicine, University of Pisa, Hospital of Cisanello, Via Paradisa, 2-56127 Pisa, Italy.E-mail:mmeola@int.med.unipi.it

(C) 2011 by the National Kidney Foundation, Inc.

0272-6386/\$36.00

doi:10.1053/j.ajkd.2011.03.030 
calcium-phosphorous product was $49 \mathrm{mg}^{2} / \mathrm{dL}^{2}\left(4.17 \mathrm{mmol}^{2} / \mathrm{L}^{2}\right)$, intact PTH (iPTH) level was 611 pg/mL (611 ng/L), and alkaline phosphatase level was $580 \mathrm{U} / \mathrm{L}$.

\section{Imaging Studies}

In 1990, color Doppler US showed nodular hyperplasia of the right inferior parathyroid gland. The gland measured $13 \times 10 \times 8$ $\mathrm{mm}$ with a calculated volume of $543 \mathrm{~mm}^{3}$. In 1993, the volume of the right inferior gland was $4,260 \mathrm{~mm}^{3}$, and a small left hypoechoic parathyroid with abnormal size $(5 \times 3 \times 4 \mathrm{~mm}$; volume, $31 \mathrm{~mm}^{3}$ ) became evident.

In 1994, color Doppler US showed a further increase in volume of the right inferior parathyroid $(23 \times 19 \times 20 \mathrm{~mm}$; volume, 4,556 $\left.\mathrm{mm}^{3}\right)$ and the left gland $\left(81 \mathrm{~mm}^{3}\right)$. Subtraction scintigraphy showed only hyperaccumulation of radiotracer near the right inferior pole of the thyroid. From 1997 to 2003, both glands increased in size $\left(5,299\right.$ and $\left.210 \mathrm{~mm}^{3}\right)$ and an enlarged parathyroid gland $\left(65 \mathrm{~mm}^{3}\right)$ was noted at the inferior pole of the left thyroid lobe.

In January 2005, color Doppler US showed 4 hyperplastic parathyroid glands. On the right side, the biggest gland was $22 \times$ $20 \times 21 \mathrm{~mm}$ with a volume of $4,827 \mathrm{~mm}^{3}$ and appeared hypervascularized. The second gland was in the superior mediastinum on the right side and measured $9 \times 7 \times 5 \mathrm{~mm}$ with a volume of 164 $\mathrm{mm}^{3}$. On the left side, there were 2 parathyroid glands measuring $11 \times 8 \times 7 \mathrm{~mm}$ with a volume of $321 \mathrm{~mm}^{3}$ (superior) and $9 \times 8 \times$ $7 \mathrm{~mm}$ with a volume of $263 \mathrm{~mm}^{3}$ (inferior). Color Doppler showed a hypervascularized pattern.
In 2006, color Doppler US showed a small volume increase in the right inferior parathyroid gland due to cyst-like involutions and widespread hypovascularization. The decrease in volume of the other glands was not significant; however, intraglandular cyst-like areas were noted in the bigger glands.

In 2007, color Doppler US showed wide cystic degeneration of the largest gland, which appeared completely avascularized on color Doppler. A decrease in volume and structural alterations of the smaller gland (cystic areas and loss of color Doppler signal) became more evident. To evaluate the functional significance of the cyst-like involutions, technetium $99 \mathrm{~m}\left({ }^{99 \mathrm{~m}} \mathrm{Tc}\right)$ methoxyisobutyl isonitrile scintigraphy was performed. This showed an area of early and late hyperaccumulation of tracer near the inferior pole of the thyroid, but did not identify other glands.

In January 2010, color Doppler US showed that the right inferior gland was $22 \times 17 \times 20 \mathrm{~mm}$ with a volume of $3,979 \mathrm{~mm}^{3}$, and its morphologic and vascular patterns were unchanged. The mediastinal gland was hyperechoic and measured $6 \times 5 \times 3 \mathrm{~mm}$ with a volume of $47 \mathrm{~mm}^{3}$, the left superior gland was $9.9 \times 5.3 \times 4.2 \mathrm{~mm}$ with a volume of $214 \mathrm{~mm}^{3}$ and absence of vascularization, and the left inferior gland was no longer distinguishable (Fig 1).

\section{Diagnosis}

SHPT in a maintenance HD patient.

\section{Clinical Follow-up}

Laboratory data, imaging findings, and therapeutic interventions are listed in Table 1.

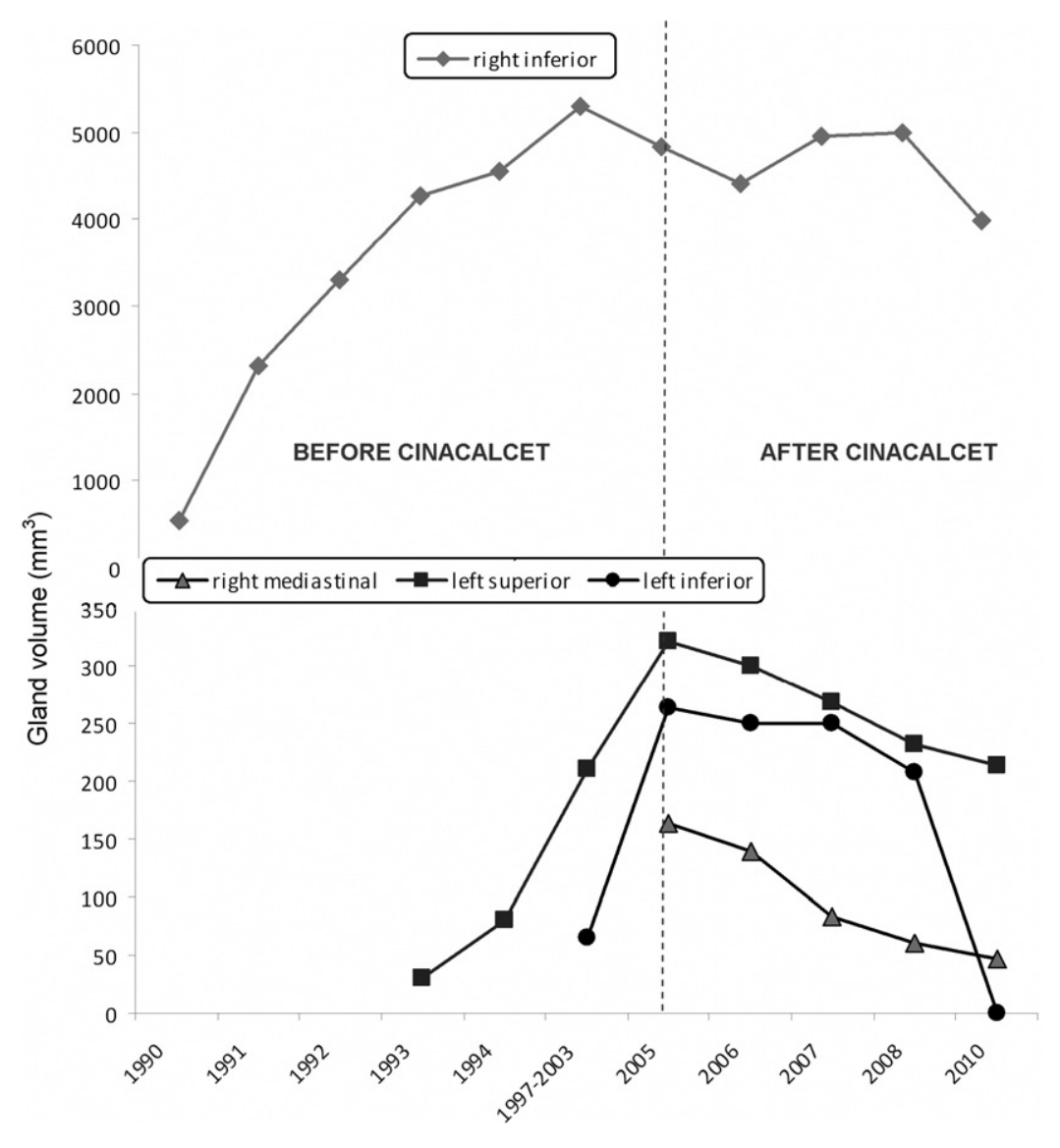

Figure 1. Volumetric variations of the parathyroid glands from 1990 to 2010. 
Table 1. Clinical History of Patient With SHPT

\begin{tabular}{|c|c|c|c|}
\hline Year & Clinical and Laboratory Findings & Parathyroid Gland Imaging ${ }^{a}$ & Treatment Decision \\
\hline 1990 & $\begin{array}{l}\mathrm{Ca}, 11 \mathrm{mg} / \mathrm{dL} ; \mathrm{P}, 4.9 \mathrm{mg} / \mathrm{dL} ; \mathrm{Ca} \times \mathrm{P}, 49 \\
\mathrm{mg} / \mathrm{dL}^{2} ; \mathrm{ALP}, 580 \mathrm{U} / \mathrm{L} ; \mathrm{iPTH}, 611 \mathrm{pg} / \\
\mathrm{mL}\end{array}$ & $\mathrm{RIG}, 543 \mathrm{~mm}^{3}$ & $\begin{array}{l}\text { PEI of the only hyperplastic } \\
\text { parathyroid gland detectable on US }\end{array}$ \\
\hline 1990 & $\begin{array}{l}9 \text { mo after PEI treatment: ALP, } 952 \mathrm{U} / \mathrm{L} \text {; } \\
\text { iPTH, } 795 \mathrm{pg} / \mathrm{mL}\end{array}$ & & \\
\hline 1993 & ALP, 500 U/L; iPTH, 700 pg/mL & RIG, 4,260 mm³ LSG, $31 \mathrm{~mm}^{3}$ & $\begin{array}{l}\text { Vitamin } \mathrm{D}(4 \mu \mathrm{g} 3 \times / \mathrm{wk}) ; \mathrm{CaCO}_{3} \\
\quad \text { decreased to } 2-3 \mathrm{~g} / \mathrm{d}\end{array}$ \\
\hline 1994-1996 & ALP, 400-265 U/L; iPTH, 670-450 pg/mL & $\mathrm{RIG}, 4,556 \mathrm{~mm}^{3} ; \mathrm{LSG}, 81 \mathrm{~mm}^{3}$ & $\begin{array}{l}\text { Oral calcitriol replaced by IV calcitriol, } \\
1.5 \mu \mathrm{g} 3 \times / \mathrm{wk} ; \mathrm{CaCO}_{3} \text { stopped; } \\
\left.\mathrm{Al}(\mathrm{OH})_{3} \text { added ( } 3 \text { tablets } 2 \times / \mathrm{wk}\right)\end{array}$ \\
\hline $1997-2003$ & $\begin{array}{l}\mathrm{Ca}, 12.3 \mathrm{mg} / \mathrm{dL} ; \mathrm{P}, 5.6 \mathrm{mg} / \mathrm{dL} ; \mathrm{Ca} \times \mathrm{P} \text {, } \\
68.8 \mathrm{mg} / \mathrm{dL}^{2} ; \text { ALP, } 326 \mathrm{U} / \mathrm{L} ; \text { iPTH, } \\
\text { 1,350 pg/mL; symptoms: itching, } \\
\text { severe osteoarticular/muscle pain, } \\
\text { lumbosacral tenderness, walking } \\
\text { difficulties }\end{array}$ & $\begin{array}{l}\mathrm{RIG}, 5,299 \mathrm{~mm}^{3} ; \text { LSG, } 210 \\
\mathrm{~mm}^{3} ; \mathrm{LIG}, 65 \mathrm{~mm}^{3}\end{array}$ & $\begin{array}{l}\text { Calcitriol therapy interrupted due to } \\
\text { episodes of hypercalcemia and } \\
\text { hyperphosphatemia; } \\
\text { parathyroidectomy indicated, but } \\
\text { patient refused; calcitriol therapy } \\
\text { reintroduced }\end{array}$ \\
\hline 2005 & $\begin{array}{l}\mathrm{Ca}, 10.1 \mathrm{mg} / \mathrm{dL} ; \mathrm{P}, 6 \mathrm{mg} / \mathrm{dL} ; \mathrm{Ca} \times \mathrm{P} \\
60.6 \mathrm{mg}^{2} / \mathrm{dL}^{2} ; \mathrm{ALP}, 740 \mathrm{U} / \mathrm{L} ; \mathrm{iPTH}, \\
1,480 \mathrm{pg} / \mathrm{mL}\end{array}$ & $\begin{array}{l}\mathrm{RIG}, 4,827 \mathrm{~mm}^{3} ; \mathrm{RMG}, 164 \\
\mathrm{~mm}^{3} ; \mathrm{LSG}, 321 \mathrm{~mm}^{3} ; \mathrm{LIG} \\
263 \mathrm{~mm}^{3} ; \text { vascular pattern } 3 \\
\text { for all }\end{array}$ & $\begin{array}{l}\text { Calcitriol replaced by IV paricalcitol ( } 5 \\
\mu \mathrm{g} 3 \times / \mathrm{wk}) \text { associated with } \\
\text { sevelamer }(4,800 \mathrm{mg} / \mathrm{d}) \text { and } \\
\mathrm{CaCO}_{3}(2 \mathrm{~g} / \mathrm{d})\end{array}$ \\
\hline 2005 & $\begin{array}{l}\mathrm{Ca}, 10.5 \mathrm{mg} / \mathrm{dL} ; \mathrm{P}, 5 \mathrm{mg} / \mathrm{dL} ; \mathrm{Ca} \times \mathrm{P}, \\
52.5 \mathrm{mg}^{2} / \mathrm{dL}^{2} ; \mathrm{ALP}, 1,243 \mathrm{U} / \mathrm{L} ; \mathrm{iPTH}, \\
1,600 \mathrm{pg} / \mathrm{mL}\end{array}$ & & $\begin{array}{l}\text { Cinacalcet (maximum dosage, } 150 \\
\mathrm{mg} / \mathrm{d} \text { ) added to conventional } \\
\text { therapy }\end{array}$ \\
\hline 2010 & $\begin{array}{l}\mathrm{Ca}, 8.6 \mathrm{mg} / \mathrm{dL} ; \mathrm{P}, 5 \mathrm{mg} / \mathrm{dL} ; \mathrm{Ca} \times \mathrm{P}, 43 \\
\mathrm{mg}^{2} / \mathrm{dL}^{2} ; \mathrm{ALP}, 316 \mathrm{U} / \mathrm{L} ; \mathrm{iPTH}, 360-400 \\
\mathrm{pg} / \mathrm{mL}\end{array}$ & $\begin{array}{l}\text { RIG, } 3,979 \mathrm{~mm}^{3} \text { (cystic } \\
\text { degeneration; vascular } \\
\text { pattern 0); RM, } 47 \mathrm{~mm}^{3} \\
\text { (vascular pattern 0); LSG, } \\
214 \mathrm{~mm}^{3} \text { (vascular pattern } \\
\text { 0); } \text { LIG }^{\mathrm{b}}\end{array}$ & $\begin{array}{l}\text { Cinacalcet }(120 \mathrm{mg} / \mathrm{d}) \text {, paricalcitol (5 } \\
\mu \mathrm{g} 3 \times / \mathrm{wk}) \text { associated with } \\
\text { sevelamer }(4,800 \mathrm{mg} / \mathrm{d}) \text { and } \\
\mathrm{CaCO}_{3}(2 \mathrm{~g} / \mathrm{d})\end{array}$ \\
\hline
\end{tabular}

Note: Conversion factors for units: serum Ca in $\mathrm{mg} / \mathrm{dL}$ to $\mathrm{mmol} / \mathrm{L}, \times 0.2495$; serum $\mathrm{P}$ in $\mathrm{mg} / \mathrm{dL}$ to $\mathrm{mmol} / \mathrm{L}, \times 0.3229 ; \mathrm{Ca} \times \mathrm{P}_{\mathrm{in}} \mathrm{mg}^{2} / \mathrm{dL}^{2}$ to $\mathrm{mmol}^{2} / \mathrm{dL}^{2}, \times 0.077$. No conversion necessary for $\mathrm{PTH}$ in $\mathrm{pg} / \mathrm{mL}$ and $\mathrm{ng} / \mathrm{L}$.

Abbreviations and definitions: $\mathrm{Al}(\mathrm{OH})_{3}$, aluminum hydroxide; $\mathrm{ALP}$, alkaline phosphatase; $\mathrm{Ca}$, calcium; $\mathrm{Ca} \times \mathrm{P}$, calcium-phosphorus product; $\mathrm{CaCO}_{3}$, calcium carbonate; iPTH, intact parathyroid hormone; IV, intravenous; LIG, left inferior parathyroid gland; LSG, left superior parathyroid gland; $\mathrm{P}$, phosphorus; $\mathrm{PEI}$, percutaneous ethanol injection; RIG, right inferior parathyroid gland; RMG, right mediastinic parathyroid gland; SHPT, secondary hyperparathyroidism; US, ultrasonography.

aVolume and (when applicable) vascular pattern assessed using color Doppler US.

${ }^{b}$ No longer distinguishable.

\section{DISCUSSION}

Color Doppler US of the parathyroid glands has a pivotal role in the diagnosis of SHPT, assessing the severity of disease and evaluating response to medical treatment. However, in clinical practice, color Doppler US is not commonly performed and SHPT diagnosis is based on iPTH serum levels and parameters of mineral metabolism.

Because parathyroid glands normally are heavily populated with adipose cells, they can be difficult to distinguish from thyroid parenchyma even with the use of high-resolution probes. ${ }^{7}$ However, cellular hyperplasia makes the glands diffusely hypoechoic and easily detectable in the thyroid lodge. There is no set size threshold above which a parathyroid gland is identified as pathologic; however, if each of 2 diameters is $>5 \mathrm{~mm}$, a hypoechoic gland is judged hyperplastic $^{8}$ (Fig 2). Glandular volume (in cubic millime- ters) is calculated using the formula of an irregular ellipsoid $\left({ }^{4} / 3 \pi \times 1 / 2\right.$ anteroposterior diameter $\times 1 / 2$ laterolateral diameter $\times 1 / 2$ craniocaudal diameter).

The increase in glandular volume suggests increased PTH secretion and worsening of SHPT. ${ }^{9}$ Studies that correlate glandular volume with histologic features of the excised glands at parathyroidectomy show that glands $<500 \mathrm{~mm}^{3}$ are affected mainly by diffuse and polyclonal hyperplasia, whereas glands $>500 \mathrm{~mm}^{3}$ are affected by monoclonal nodular hyperplasia in $80 \%$ of cases. Moreover, because there is wide variation in glandular volume, the overall sensitivity of color Doppler US in SHPT diagnosis is $74 \%-75 \%(<50 \%$ in the localization of parathyroids $<500 \mathrm{~mm}^{3}$ and $>90 \%$ in glands $\left.\geq 500 \mathrm{~mm}^{3}\right){ }^{10}$

The ability to assess changes in glandular volume gives color Doppler US a unique advantage over SPECT (single-photon emission computed tomogra- 


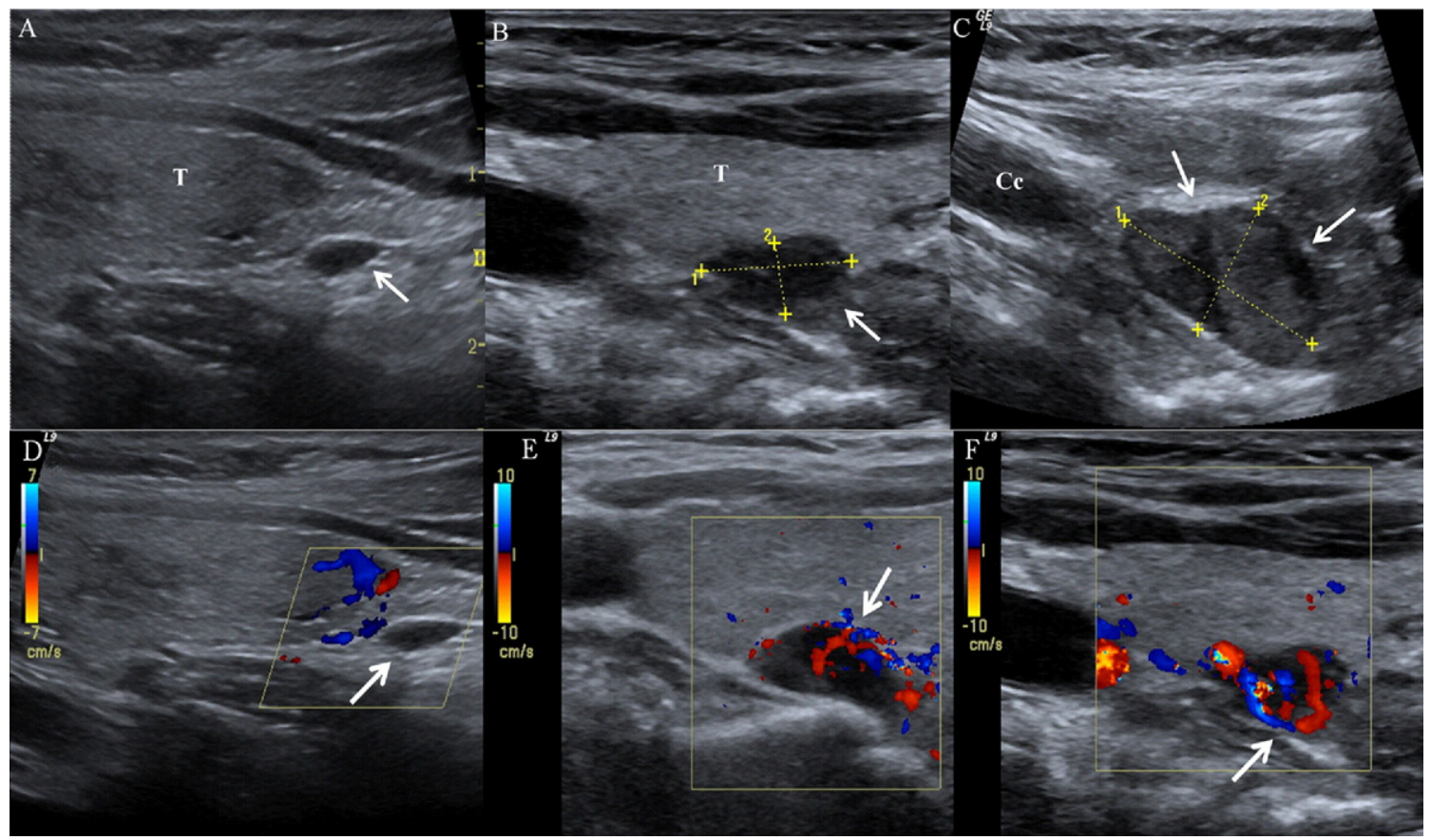

Figure 2. Progression of parathyroid gland hyperplasia. (A) Long-term hyperstimulation of parathyroid glands causes hyperplasia that makes the glands enlarged and diffusely hypoechoic (arrows), easily distinguishable in the thyroid lodge. (B, C) Glandular hyperplasia is at first diffuse and polyclonal, then monoclonal and nodular. The increase in parathyroid gland volume is associated with a widespread increase in vascularity. Color Doppler distinguishes 3 different patterns: (D) glands lacking Doppler signal, (E) hypovascularized glands with only a few color spots in the hilar/endonodular region (weak Doppler signal), and (F) hypervascularized glands fed by an enlarged hilar artery that have a peripheral arc of vascularity and/or ray-like endonodular vessels. Abbreviations: Cc, common carotid; $\mathrm{T}$, thyroid.

phy)-scintigraphy, computed tomography, and magnetic resonance imaging.

The increase in parathyroid gland volume is associated with a widespread increase in vascularity, evident histologically. ${ }^{11-13}$ Usually color Doppler distinguishes 3 different patterns, ${ }^{10}$ as shown in Fig 2D-F.

According to international guidelines, SHPT diagnosis is based on iPTH serum levels and parameters of mineral metabolism. However, the optimal values for iPTH in maintenance HD patients are still uncertain, ${ }^{14,15}$ and hormone levels show great variability. ${ }^{16}$ Because levels are influenced by drug therapy, iPTH level does not provide information for grading hyperplasia. Color Doppler US evaluates the degree of hyperplasia and number of glands involved, completing the biochemical diagnosis. We routinely perform color Doppler US of the parathyroid glands when iPTH values are consistently $>400 \mathrm{pg} / \mathrm{mL}(>400$ $\mathrm{ng} / \mathrm{L}$ ) and repeat this study annually in maintenance HD patients to evaluate the progression of disease. B-Mode parameters important for the assessment of SHPT progression include: (1) the gland's echogenicity, (2) gland diameter ${ }^{17}$ and volume, (3) appearance of anechoic areas with no vascularization suggesting involutive cystic phenomena, and (4) presence of fibrocalcifications. ${ }^{13}$
In our case, nodular hyperplasia of a single gland appeared after a long period of maintenance HD therapy. Color Doppler US was used to perform chemical ablation with percutaneous ethanol injection, but biochemical/morphologic results were poor. Afterward, other hyperplastic glands appeared, showing the slow but continuous progression of SHPT despite oral/intravenous vitamin D treatments. At this stage, the evidence of nodular hyperplasia on color Doppler US, severity of SHPT, and refractoriness to therapy with vitamin D/binders indicated the necessity of parathyroidectomy, which was refused by the patient.

The role of color Doppler US in the presurgical evaluation of SHPT is very different from primary hyperparathyroidism. The sensitivity of color Doppler US in the localization of adenoma/carcinoma is very high (90\%-92\%) for primary hyperparathyroidism, similar to that of conventional parathyroidectomy (93\%-99\%). ${ }^{18}$ In a patient with SHPT, the role of imaging is less critical because parathyroidectomy is performed using conventional cervicotomy. Moreover, because there is wide variation in glandular volume and the overall sensitivity of color Doppler US for SHPT is lower than for primary hyperparathyroidism, the role of color Doppler US therefore should 
not be to localize the glands, but instead to determine surgical timing. Parathyroidectomy is indicated when color Doppler US evidences one or more hyperplastic glands $\geq 500 \mathrm{~mm}^{3}$, serum iPTH level is $>700 \mathrm{pg} / \mathrm{mL}$ ( $>700 \mathrm{ng} / \mathrm{L}$ ), and calcium, phosphorus, and calciumphosphorous product values are no longer controlled using conventional therapy. ${ }^{19,20}$

Glandular volume is related directly to the number of glands detected; it also may be highly variable and not entirely correlated with iPTH level at greater than a certain size/volume threshold. Calculated volume shows a linear correlation with iPTH value only when gland volume is $<2,000 \mathrm{~mm}^{3}$ (ie, $<2 \mathrm{~g}$ ). ${ }^{8,21}$ This observation suggests that the biggest glands tend to disengage from receptor control mechanisms (ie, upregulation of calcium receptor and vitamin D receptor) and grow independently.

In our patient, the combination of conventional therapy and cinacalcet marked a reversal in the progression of disease: PTH serum levels were decreased, mineral metabolism was stabilized, and color Doppler US showed progressive changes in volume and vascularization. The regression resembled a "chemical parathyroidectomy," and 5 years after beginning therapy, surgical parathyroidectomy was not necessary.
Color Doppler US showed a volume decrease associated with loss of vascular signal, progressing to complete disappearance of vascularization in the biggest glands ( $\geq 500 \mathrm{~mm}^{3}$; Fig 3$)$. Most glands involute (cystic-like lesions; Fig 4), whereas glands $<500$ $\mathrm{mm}^{3}$ show a volume decrease accompanied by a structural change toward hyperechogenicity, as if the relationship between cellularity and stromal adipose tissue had been reversed. This suggests that calcimimetic treatment modulates the biological response of cells with uncontrolled proliferation through direct stimulation of calcium receptor and vitamin D receptor expression. ${ }^{18}$

In conclusion, if iPTH serum levels are constantly $>400 \mathrm{pg} / \mathrm{mL}$ (>400 ng/L), color Doppler US can be performed to evaluate the presence of hyperplastic glands and complete the clinical diagnosis. This can be repeated once a year to evaluate disease progression. The availability of calcimimetics is changing the natural history of SHPT and may change the therapeutic utility of surgical parathyroidectomy. Use of color Doppler US further supports these therapeutic advances, allowing evaluation of morphologic and vascular changes in hyperplastic glands and aiding clinical, pharmacologic, and surgical strategies.
Figure 3. Right inferior parathyroid gland of clinical case before and after cinacalcet therapy. (A) Before cinacalcet therapy, diameters were $22 \times 20 \times 21$ $\mathrm{mm}$ (volume, $4,827 \mathrm{~mm}^{3}$ ) and the gland was diffusely hypoechoic. (B) The vascular pattern was rich (type 3) and showed a vascular hilum. T, thyroid. (C) After 2 years of cinacalcet combined therapy, the gland was $21 \times 21 \times 21 \mathrm{~mm}$ $\left(4,838 \mathrm{~mm}^{3}\right)$ and color Doppler ultrasonography showed wide cystic degeneration (D) with disappearance of vascularization. Abbreviation: $\mathrm{T}$, thyroid.

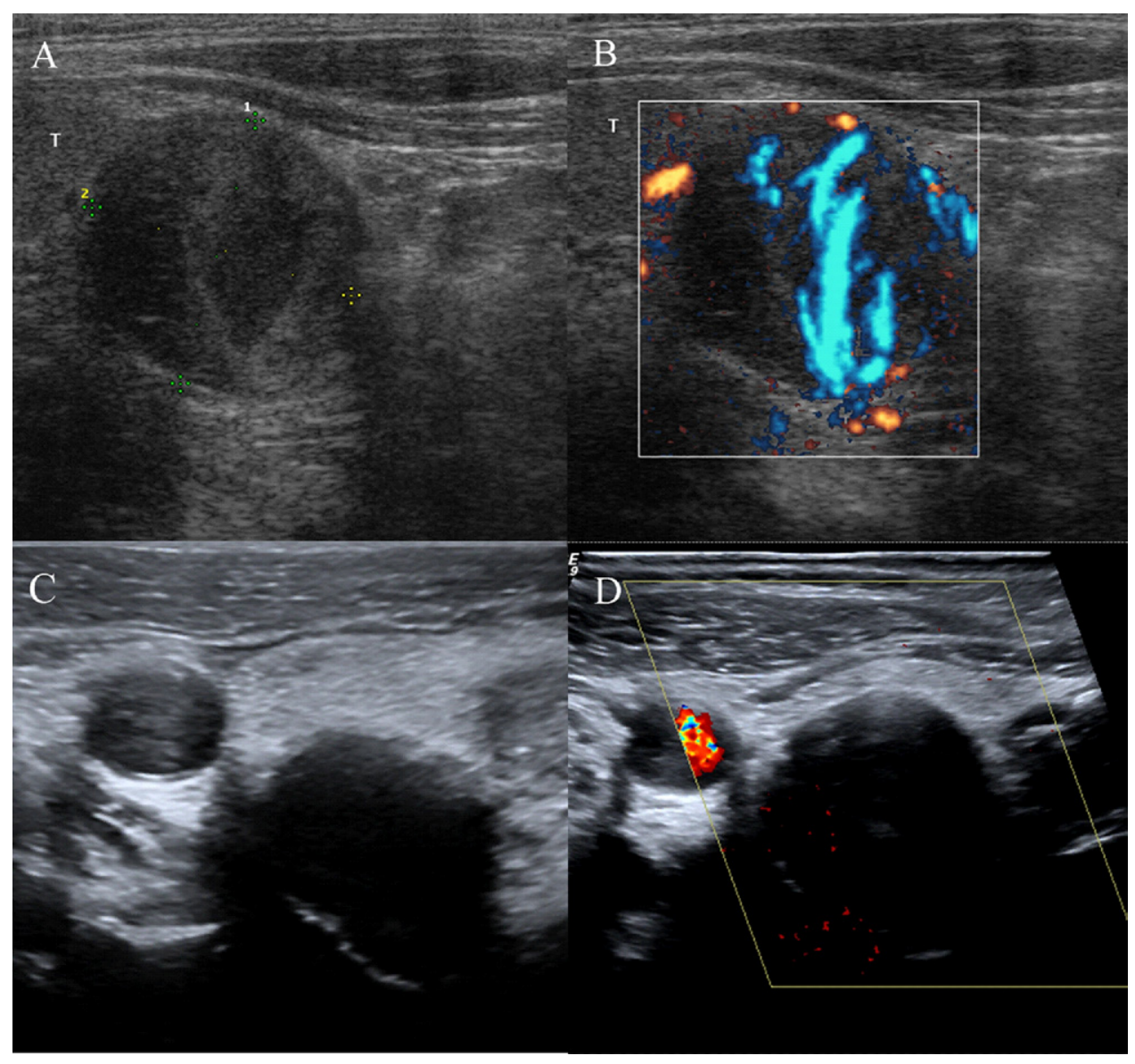




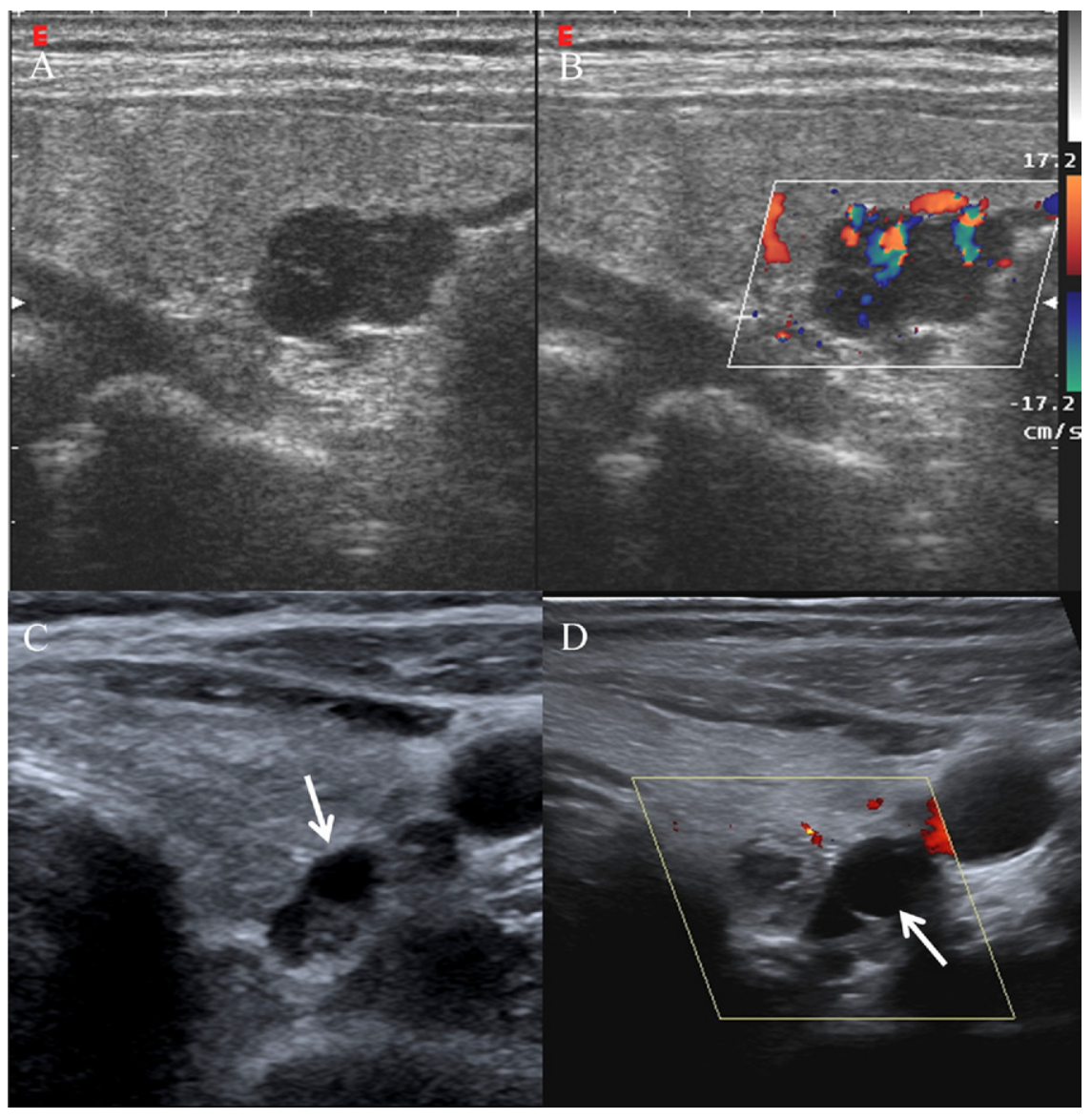

Figure 4. (A) Morphologic changes in the left superior parathyroid gland of the clinical case. (B) Before cinacalcet therapy, the gland was hypoechoic with a solid appearance and showed diffused hypervascularization. (C) After 5 years of conventional therapy associated with cinacalcet, the gland shows areas of cystic degeneration (arrows) (D) with no Doppler signal.

\section{ACKNOWLEDGEMENTS}

We thank Sara Samoni, MD, for collecting clinical data.

Support: An unrestricted grant from Amgen Europe $\mathrm{GmbH}$ funded English translation by Apothecom ScopeMedical Ltd.

Financial Disclosure: The authors declare that they have no relevant financial interests.

\section{REFERENCES}

1. Drüeke TB. Cell biology of parathyroid gland hyperplasia in chronic renal failure. J Am Soc Nephrol. 2000;11(6):11411152 .

2. Bethmore JB, Quarles LD. Calcimimetics or vitamin D analogs for suppressing parathyroid hormone in end-stage renal disease: time for a paradigm shift? Nat Clin Pract Nephrol. 2009;5(1):24-33

3. Fukagawa M. Cell biology of parathyroid hyperplasia in uremia. Am J Med Sci. 1999;317(6):377-382.

4. Arnold A, Brown MF, Urena P, et al. Monoclonality of parathyroid tumors in chronic renal failure and in primary parathyroid hyperplasia. J Clin Invest. 1995;95(5):2047-2053.

5. Afonso S, Santamaría I, Guinsburg ME, et al. Chromosomal aberrations, the consequence of refractory hyperparathyroidism: its relationship with biochemical parameters. Kidney Int Suppl. 2003;63(85):S32-38.

6. Meola M, Petrucci I, Barsotti G. Long-term treatment with cinacalcet and conventional therapy reduces parathyroid hyperplasia in severe secondary hyperparathyroidism. Nephrol Dial Transplant. 2009;24(3):982-989.

7. Pavlović D, Brzac HT. Prevention and treatment of secondary hyperparathyroidism: still a challenge for the nephrologist? Nephrol Dial Transplant. 2003;18(suppl 5):v45-46.
8. Indridason OS, Heath H III, Khosla S, Yohay DA, Quarles LD. Non suppressible parathyroid hormone secretion is related to gland size in uremic secondary hyperparathyroidism. Kidney Int. 1996;50(5):1663-1667.

9. Périé S, Fessi H, Tassart M, et al. Usefulness of combination of high-resolution ultrasonography and dual-isotope iodine 123/technetium Tc $99 \mathrm{~m}$ sestamibi scintigraphy for the preoperative localization of hyperplastic parathyroid glands in renal hyperparathyroidism. Am J Kidney Dis. 2005;45(2):344352.

10. Meola M, Petrucci I, Calliada F, et al. Presurgical setting of secondary hyperparathyroidism using high-resolution sonography and color Doppler. Ultraschall Med. 2011;32(suppl 1): S74-82.

11. Calliada F, Sala G, Conti MP, et al. Clinical applications of color-Doppler: the parathyroid glands. Radiol Med. 1993; 85(5)(suppl 1):S114-119.

12. Lane MJ, Desser TS, Weigel RJ, Jeffrey RB. Use of color and power Doppler sonography to identify feeding arteries associated with parathyroid adenomas. AJR Am J Roentgenol. 1997; 171(3):819-823.

13. Gooding GA, Clark OH. Use of color Doppler imaging in the distinction between thyroid and parathyroid lesions. Am J Surg. 1992;164(1):51-56.

14. National Kidney Foundation. K/DOQI Clinical Practice Guidelines for Bone Metabolism and Disease in Chronic Kidney Disease. Guidelines evaluation of calcium and phosphorous metabolism. Am J Kidney Dis. 2003;42(suppl 3):S52-57.

15. Moe SM, Drüeke TB, Block GA, et al. KDIGO clinical practice guidelines for diagnosis, evaluation, prevention, and treatment of chronic kidney disease-mineral and bone disorder 
(CKD-MBD). Treatment of CKD-MBD targeted at lowering high serum phosphorus and maintaining serum calcium. Kidney Int Suppl. 2009;76(113):S50-90.

16. Souberbielle JC, Boutten A, Carlier M-C, et al. Working Group on PTH and Vitamin D. Société Francaise de Biologie Clinique. Inter-method variability in PTH measurement: implication for the care of CKD patients. Kidney Int. 2006;70(2): 345-350.

17. Vulpio C, Bossola M, De Gaetano A, et al. Ultrasound patterns of parathyroid glands in chronic hemodialysis patients with secondary hyperparathyroidism. Am J Nephrol. 2008;28(4): 589-597.
18. Elder GJ. Parathyroidectomy in the calcimimetic era. $\mathrm{Ne}$ phrology. 2005;10(5):511-515.

19. Schomig M, Ritz E. Indications for parathyroidectomy. Nephrol Dial Transplant. 2000;15(suppl 5):S25-29.

20. Tominaga Y, Matsuoka S, Sato T. Surgical indications and procedures of parathyroidectomy in patients with chronic kidney disease. Ther Apher Dial. 2005;9(1):44-47.

21. Tominaga Y, Matsuoka S, Sato T, et al. Clinical features and hyperplastic patterns of parathyroid glands in hemodialysis patients with advanced secondary hyperparathyroidism refractory to maxacalcitol treatment and required parathyroidectomy. Ther Apher Dial. 2007;11(4):266-273. 